\title{
PANDUAN PENULISAN UJIAN TENGAH SEMESTER
}

\section{MATA KULIAH: METODE PENELITIAN KUALITATIF}

\author{
Ismail Suardi Wekke \\ Sekolah Tinggi Agama Islam Negeri (STAIN) Sorong \\ Email: ismail@stain-sorong.ac.id
}

\begin{abstract}
ABSTRAK
Artikel ini merupakan panduan dalam pelaksanaan latihan dalam rangka penilaian ujian tengah semester. Setiap mahasiswa menyiapkan artikel dan kemudian diunggah ke Academia.
\end{abstract}

Kata kunci: artikel, penelitian, ekonomi syariah.

\section{PENDAHULUAN}

Perkuliahan Metode Penelitian Kualitatif bertujuan untuk memberikan latihan sehingga mahasiswa memiliki kemampuan untuk meneliti. Maka, fase sekarang adalah berlatih untuk mengidentifikasi sebuah masalah penelitian. Untuk itu, artikel ini menjadi panduan penulisan artikel untuk aktivitas kedelapan sebagai Ujian Tengah Semester (UAS). Keberadaan perguruan tinggi di Tanah Papua sejatinya perlu juga memulai prakarsa untuk terlibat dalam diskursus kecenderungan akademik dunia (Wekke, Kahar, \& Amri, 2018).

\section{PEDOMAN UMUM}

Artikel (bukan makalah) ditulis dengan ketentuan:

1. Topik yang ditulis "masalah ekonomi syariah Indonesia". Bisa juga dengan aspek yang lebih spesifik dari topik tersebut dengan menganalisis perbankan, keuangan, atau akuntasi, dll;

2. Minimal 3 halaman dengan spasi 1,5, tidak termasuk daftar pustaka;

3. Media kertas yang digunakan berupa A4 dengan margin empat sisi $2 \mathrm{CM}$;

4. Struktur artikel terdiri atas pendahuluan, sub-sub judul, penutup, dan daftar pustaka;

5. Daftar pustaka yang dirujuk minimal 10 yang terdiri hanya dari buku atau jurnal (boleh dalam bentuk jurnal online). Tidak boleh menggunakan Wikipedia, Blogspot, atau Wordpres. 
6. Penulisan artikel tidak boleh plagiat, jikalau ini dilakukan otomatis tidak mendapatkan nilai apa-apa. Sebaliknya, artikel ditulis dengan analisis dan juga paraphrase.

7. Batas akhir pengunggahan ke Academia, Jumat (25/1) 2019 pukul 23.59 WIT.

\section{KOMPONEN ARTIKEL}

Sebuah artikel paling tidak harus punya kandungan scientific. Masalah yang dikemukakan merupakan sebuah fenomena (Wekke, 2018). Tidak boleh hanya sekadar opini belaka, melainkan terdapat data. Selanjutnya data tersebut juga dianalisis dan ditunjukkan dengan perbandingan apa yang sudah dipublikasi dalam jurnal (Sarwono, 2010). Hakekat karya ilmiah sejatinya adalah sumbangan bagi kemajuan masyarakat sehingga tidak bisa alasan keasyikan keilmuan semata dijadikan sebagai tujuan (Brew \& Wekke, 2018).

Kedua, tidak memungkinkan sama sekali plagiat alias copy paste. Ketika hanya salin dan temple, maka saat ini sudah tersedia software yang dapat mengecek tingkat kesamaan artikel, sehingga tidak bisa bersembunyi dari itu semua. Ketidakjujuran dalam penulisan akademik menjadi sebuah masalah tersendiri saat ini dimana kalangan akademik kadang tergoda untuk melakukan ketidakjujuran (Ardinansyah, Tenrisau, Aslim, \& Wekke, 2018).

Terakhir, dengan menggunakan instrumen teknologi informasi akan membantu meningkatkan mutu artikel (Nur, Sabara, \& Wekke, 2018). Dengan pelbagai alat teknologi informasi yang tersedia akan memudahkan proses penulisan artikel.

\section{PENUTUP}

Demikian pedoman ini untuk dijadikan acuan. Dengan demikian, apa yang tidak diatur dalam dalam artikel ini sepenuhnya menjadi pilihan mahasiswa untuk dilakukan. Sementara ketentuan dalam artikel untuk memudahkan mahasiswa dan dosen diatur untuk menjadi acuan.

\section{DAFTAR PUSTAKA}

Ardinansyah, A., Tenrisau, D., Aslim, F., \& Wekke, I. S. (2018). Ketidakjujuran Akademik Dalam Pendidikan Tinggi.

Brew, A., \& Wekke, I. S. (2018). Hakikat Karya Ilmiah (The Nature of Research). Deepublish.

Nur, T., Sabara, H. Z., \& Wekke, I. S. (2018). Teknik Menulis Karya Ilmiah: Dengan 8 Senjata Aplikasi Pendukung Produktivitas Riset. Deepublish. 
Sarwono, J. (2010). Pintar Menulis Karangan Ilmiah-Kunci Sukses dalam Menulis Ilmiah. Penerbit Andi.

Wekke, I. S. (2018). Memulai Identifikasi Masalah Penelitian. OpenWekke, Ismail S. "MEMULAI IDENTIFIKASI MASALAH PENELITIAN". INA-Rxiv, 19.

Wekke, I. S., Kahar, M. S., \& Amri, I. (2018). Perguruan Tinggi Tanah Papua Dan Strategi Pengembangan Pendidikan Tinggi. OpenWekke, Ismail S, Muhammad S Kahar, and Irman Amri. "PERGURUAN TINGGI TANAH PAPUA DAN STRATEGI PENGEMBANGAN PENDIDIKAN TINGGI”. INA-Rxiv, 20. 